DOI https://doi.org/10.30525/978-9934-588-91-4-30

\title{
ВПЛИВ КІНЕМАТОГРАФУ НА ФОРМУВАННЯ ЕМОЦІЙНИХ МАТРИЦЬ ПОЛІТИЧНОЇ СПІЛЬНОТИ
}

\author{
Білозерова Я. В. \\ аспірант кафедри політологї \\ Одеського національного університету імені I. І. Мечникова \\ м. Одеса, Україна
}

Ступінь впливу доктринальних політичних концепцій на поведінку членів конкретного соціуму безпосередньо залежить від їхньої відповідності тим «емоційним матрицям», які входять до культурного коду великої соціальної спільноти та виступають і як примордіальні феномени, і як артефакти, створені різноманітними елітами. Цей аспект інжинірингової діяльності тандемів політичних та творчих еліт, що має на меті імплементацію до масової свідомості стандартизованих колективних реакцій на типові суспільно-політичні процеси та явища («емоційні матриці» в термінології А. Зоріна) викликає сталий інтерес 3 боку наукової спільноти. Особливу актуальність має дослідження спроб впливу на суспільну свідомість за допомогою кіномистецтва, окремі жанри якого (історичні, патріотичні, військові) мають значну пропагандистську спрямованість та мобілізаційну здатність. Особлива увага дослідника в цьому випадку концентрується на тих фреймах (шаблонних формах сприйняття та інтерпретації сюжетних ліній), які транслюються замовниками/авторами кінострічок на реципієнтів 3 метою формування у останніх певних бажаних емоційних матриць.

Об’єктом даного дослідження постали основні смислові сюжети патріотичного сегменту російського кінематографу, які інтерпретуються як складові цілеспрямованого ідеологічного впливу на масову свідомість громадян цієї країни. В основу методики дослідження було закладено наративний контент-аналізу.

Для дослідження було обрано дев'ять художніх фільмів кінця XX початку XXI ст., пов'язаних з патріотичною тематикою, а саме: «Цар» (2009 р.) «Союз спасіння» (2019 р.), «Стомлені сонцем» (1994 р.), «Адмірал» (2008 р.), «Матильда» (2017 р.), «28 панфіловців» (2016 р.), «Ржев», «Піп» (2009 р.), «4 дні в травні» (2011 р.).

Визначено, що тип «емоційної матриці» суспільства, поданий в фільмі «Цар» [12] може бути визначений як потреба в утриманні влади в державі, захисті країни від розвалу в складні часи. Незважаючи на жорстокість царя, ігнорування ним справедливості, моралі, потреб збереження власного народу, основна сюжетна лінія вказує глядачам на 
ключову ідею щодо застосування таких методів збереження влади вимогами часу.

Виявлено, що тип «емоційної матриці» суспільства, сформованої в фільмі «Союз спасіння» [10] визначається акцентом на консерватизм владних відносин, раціоналізм правлячої верхівки та афективність заколотників.

Можна констатувати, що тип «емоційної матриці» суспільства, сформованої в фільмі «Стомлені сонцем» [11] визначається акцентом на тому, що обов'язок перед Батьківщиною вище страху за своє життя. На наш погляд, основна ідея фільму полягає не у висвітлення жорстокості, несправедливості сталінського режиму, але може бути пов'язана 3 донесенням до свідомості глядача, що в складні часи СРСР жив не тільки страхом, там були гідні, безстрашні герої.

Аналіз показав, що тип «емоційної матриці» суспільства, сформованої в фільмі «Адмірал» [6] підкреслює бажання влади сьогоднішньої Росії примирити різні групи населення, які по-різному ставляться до подій громадянської війни та її учасників. Через це подається дискурс про потребу виховання патріотизму, служіння Батьківщині, здійснюються спроби підтримання цих напрямків в свідомості росіян.

Дослідження свідчить, що тип «емоційної матриці» суспільства, сформованої в фільмі «Матильда» [7] визначається акцентом на особистій самопожертві російських царів заради держави. Зазначений фільм, як i попередня кінострічка, показує орієнтир держави у формуванні у населення гордості за визначних осіб історії, які, ігноруючи власні життєві, особисті цілі віддавали себе служінню держави. Завдяки цьому дискурсу висувається ідея стосовно жертовності правителів Росії.

Аналіз показав, що тип «емоційної матриці» суспільства, сформованої в фільмі «28 панфіловців» [13] пов’язаний з визначальною роллю радянської армії у боротьбі 3 нацистською Німеччиною. Вказаний фільм демонструє втілення концепції історичної доктрини РФ щодо так званого відновлення історичної справедливості стосовно ролі Росії у перемозі над нацистською Німеччиною. Відповідно, ідея патріотизму, історичного лідерства Росії є визначальною у формуванні «емоційної матриці» щодо даного кінофільму.

Дослідження свідчить, що тип «емоційної матриці» суспільства, сформованої в фільмі «Ржев» [9] грунтується на ідеї героїчної, відданої масовій боротьби радянської армії незважаючи на внутрішні проблеми, в тому числі каральну систему СРСР. У фільмі засуджується епоха сталінських репресій (зібрані всі штампи карального апарату), але первинною у формуванні «емоційної матриці» щодо вказаного кінофільму є ідея патріотизму солдатів, героїчних військових начальників. 
Оцінка показала, що тип «емоційної матриці» суспільства, сформованої в фільмі «Піп» [8] визначився на гуманності, антагоністичності, праведності священників православної церкви під час війни. В фільмі здійснено спробу привернути увагу до самопожертви церковних діячів часів війни, складність їх морального вибору, активну участь у підтримці народу, який залишився на окупованих територіях.

Аналіз свідчить, що тип «емоційної матриці» суспільства, сформованої в фільмі «4 дні в травні» [14] характеризується на ідеї примиренні між колишніми ворогами часів війни для протидії свавіллю та невиправданій жорстокості, на тому, що під час війни були як негативні, так і позитивні явища, вчинки з боку «переможців».

Під час дослідження виявлено, що основними змістовними елементами «емоційної матриці», яка активно імплементується в масову свідомість росіян за допомогою ідеологічно навантажених художніх фільмів є:

1. Апологія силових структур країни (передусім - армії) - 6 фільмів (66\%).

2. Консолідація населення всередині країни, незважаючи на ідейні та ідеологічні протиріччя задля здолання зовнішнього ворога 5 фільмів (55\%).

3. «Суворе, але компетентне та відповідальне керівництво/керівник» країни - 4 художні фільми (44\%).

4. Служіння своїй справі, неухильне виконання професійних обов'язків - 4 художні фільми (44\%).

6. Неприйняття «беззмістовних» революцій -2 фільми (22\%).

7. Окремою сюжетною лінією, яка простежується на прикладі фільму Цар (11\%) є «симфонія» світської та духовної влади, як однієї 3 основ російської державності.

Емоційно болісна реакція споживачів витворів кінематографу на художній фільм «4 дні в травні» (із відповідними низькими касовими зборами) свідчить про неприйнятність для росіян спроб ревізії офіційної концепції історії, про консервативність масової свідомості, неготовність до критичного сприйняття політичного розвитку своєї країни.

У сукупності своїй зміст проаналізованих художніх фільмів (враховуючи їх значні касові збори за винятком «4 роки в травні») задає для масової свідомості росіян неоімперську інтерпретацію колективної історії та сьогодення. Постаючи як складова колективного політичного дискурсу, ця інтерпретація виступає потужним засобом легітимації не лише внутрішньої, але й зовнішньої політики Росії, навіть якщо остання здійснюється із порушенням норм міжнародного законодавства по відношенню до таких країн, як Україна. 


\section{Література:}

1. Інформація про фільм «Адмірал». Дата оновлення: 24.05.2020. https://www.kino-teatr.ru/kino/movie/ros/138/annot/ (дата Звернення: 24.05.2020).

2. Інформація про фільм «Матильда». Дата оновлення: 24.05.2020. https://www.kino-teatr.ru/kino/movie/ros/100347/annot/ (дата Звернення: 24.05.2020).

3. Інформація про фільм «Поп». Дата оновлення: 24.05.2020 https://www.kino-teatr.ru/kino/movie/ros/82553/annot/ (дата Звернення: 24.05.2020).

4. Інформація про фільм «Ржев». Дата оновлення: 24.05.2020. https://www.kino-teatr.ru/kino/movie/ros/133010/annot/ (дата Звернення: 24.05.2020).

5. Інформація про фільм «Союз порятунку». Дата оновлення: 24.05.2020. https://www.kino-teatr.ru/kino/movie/ros/hud/120240/video/ (дата Звернення: 24.05.2020).

6. Інформація про фільм «Стомлені сонцем». Дата оновлення: 24.05.2020. https://www.kino-teatr.ru/kino/movie/ros/7493/annot/ (дата Звернення: 24.05.2020).

7. Інформація про фільм «Цар». Дата оновлення: 24.05.2020. https://www.kino-teatr.ru/kino/movie/ros/14592/annot/ (дата Звернення: 24.05.2020).

8. Інформація про фільм «28 панфіловців». Дата оновлення: 24.05.2020. https://www.kino-teatr.ru/kino/movie/ros/105459/annot/ (дата Звернення: 24.05.2020).

9. Інформація про фільм «4 дні в травні». Дата оновлення: 24.05.2020. https://www.kino-teatr.ru/kino/movie/ros/95841/annot/ (дата Звернення: 24.05.2020). 